\title{
KONSEP PENGENDALI LAMPU PENERANGAN RUMAH DARI JARAK JAUH MENGGUNAKAN GELOMBANG FREKUENSI
}

\author{
Danang Danang, Siswanto Siswanto \\ Sekolah Tinggi Elektronika dan Komputer (STEKOM), danang@stekom.ac.id \\ Sekolah Tinggi Elektronika dan Komputer (STEKOM), siswanto@stekom.ac.id \\ J1. Majapahit 605, Semarang, telp/fax : 024-6717201-02
}

\section{ARTICLE INFO}

Article history:

Received 30 November 2019

Received in revised form 2 Desember 2019

Accepted 10 Desember 2019

Available online 12 Desember 2019

\begin{abstract}
The Advancement of Science and Technology (Science and Technology) has been widely felt by the general public. Many people enjoy facilities or tools that can simplify and speed up their work. The advancement of science and technology covers various fields, including electronics, automotive machinery, medicine and others. Progress in the electronics sector is growing very rapidly. For example, now many electronic devices are used by the public, such as radio, television, fans and others. The advancement in the electronics field is increasingly sophisticated and modern. For example television, in ancient times we had to press the buttons that were attached to the television, to move the television waves, adjust the volume, and use other adjustment buttons. But now no longer, we can control or regulate the functions that exist on the television from where we sit using the remote control. In modern times like today remote control devices need to be developed so that we can control things from where we sit or from whatever we want, so that human work becomes easier and faster.
\end{abstract}

Keywords: advancement, control, devices

\section{Pendahuluan}

Kemajuaan Ilmu Pengetahuaan dan Ilmu Teknologi ( IPTEK ) Sudah banyak dirasakan masyarakat umum. Masyarakat banyak menikmati fasilitas atau alat - alat yang dapat mempermudah serta mempercepat pekerjaan mereka. Kemajuaan IPTEK ini meliputi berbagai bidang, diantaranya bidang elektronika, mesin - mesin otomotif, kedokteran dan lain - lain. Kemajuaan dibidang elektronika berkembang sangat pesat. Sebagai contoh sekarang banyak alat - alat elektronika yang digunakan oleh masyarakat, misalnya radio, televisi, kipas angin dan lain-lain. Kemajuaan dalam bidang elektonika ini semakin canggih serta modern. Contohnya televisi, zaman dahulu kita harus menekan tombol - tombol yang menempel pada televisi tersebut, untuk memindah gelombang televisi, mengatur volume, serta mengunakan tombol pengaturan yang lain. Namun sekarang tidak lagi, kita bisa mengendalikan atau mengatur fungsi - fungsi yang ada pada televisi tersebut dari tempat kita duduk dengan mengunakan remote kontrol. Di zaman modern seperti sekarang ini alat - alat pengendali dari jarak jauh perlu dikembangkan agar kita bisa mengendalikan sesuatu dari tempat duduk atau dari mana saja yang dikehendaki, supaya pekerjaan manusia menjadi lebih mudah dan cepat.

Untuk dapat mangendalikan sebuah lampu penerangan (on / off), kita harus menggunakan saklar sebagai pemutus dan penghubung lampu tersebut dengan jala - jala listrik dari PLN. Saklar yang sudah banyak digunakan masyarakat sebagai pengendali lampu saat ini (saat pembuatan TA ini ) adalah saklar manual yang biasanya diletakkan pada dinding - dinding ruangan. Saklar manual yang digunakan Received Nov 19, 2019; Revised Nov 23, 2019; Accepted Des 25, 2019 
mempunyai berbagai macam bentuk dan cara penggunaan. Ada yang dengan cara menekan dan ada juga yang dengan cara menarik / mendorong saklar untuk menghidupkan atau mematikan lampu.

Jika kita menggunakan saklar kontak dengan relay untuk mengendalikan lampu, maka kita bisa mengendalikanya dengan tegangan. Tegangan kerja relay pada penggunaan alat ini adalah $12 \mathrm{~V}$ dc. Setelah relay ini dikombinasikan atau dirangkaikan dengan komponen - komponen tertentu, dan menjadi sebuah saklar sinyal, maka dengan triger tegangan 3 volt DC, relay dapat dikendalikan. pada alat ini pentriger saklar sinyal akan dikirimkan dari pemancar ke penerima dengan menggunakan gelombang frekuensi. Sehingga kita bisa mengendalikan relay dari jarak jauh dengan sebuah pemancar / remote kontrol.

Alat pengendali lampu rumah dari jarak jauh ini dibangun dari beberapa komponen yang sangat sederhana. Bentuk rangkaiannya pun cukup simpel sehinga mudah dibuat. Pada dasarnya alat ini terdiri dari sebuah pemancar dari sebuah penerima gelombang frekuensi tinggi / RF ( Radio Frequency ). Gelombang RF berfungsi untuk membawa sinyal - sinyal berupa pulsa yang nantinya akan dipisahkan kembali oleh rangkaian penerima agar dapat digunakan untuk menghidupkan dan mematikan relay sebagai saklar lampu, sehingga lampu dapat dihidupkan dan dimatikan dari jarak jauh, untuk lebih jelasnya, berikut akan dibahas mengenai dasar - dasar komponen elektronika

Berdasarkan latar belakang tersebut diatas penulis membuat alat dengan judul “ KONSEP PENGENDALI LAMPU PENERANGAN RUMAH JARAK JAUH MENGGUNAKAN GELOMBANG FREKUENSI “. Hal ini dimaksudkan agar nantinya kita bisa mengendalikan lampu - lampu penerangan rumah kita dari satu tempat. Misalnya dari ruang tamu, kamar mandi, kamar tidur bisa kita kendalikan di ruang mana saja yang kita kehendaki selama masih dalam jarak jangkauan alat tersebut.

\section{Landasan Teori}

2.1 Resistor / hambatan (R)
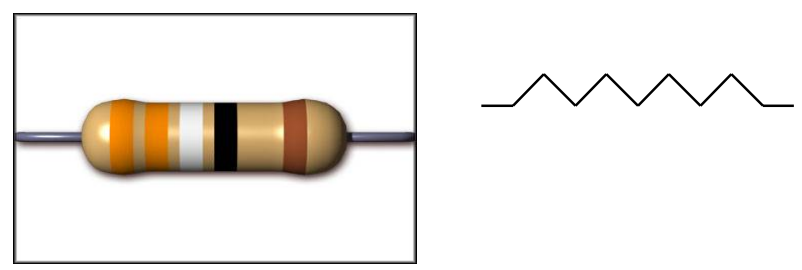

Gb 2.1. Gambar Resistor Secara Fisik dan Simbol

Simbol resistor dapat dilihat pada gambar 1. Resistor berfungsi untuk menghambat arus yang akan melewati rangkaian. Satuan hambatan adalah ohm $(\Omega)$. Dalam kenyataan untuk mengetahui nilai hambatan dari sebuah resistor kita bisa membaca kode warna yang ada pada resistor tersebut, atau bisa juga dengan mengukur nilai hambatannya dengan menggunakan alat ukur ohm meter. Resistor mempunyai kode warna yang masing-masing warna mempunyai nilai sendiri-sendiri, seperti ditunjukkan pada tabel $2.1 \&$ tabel 2.2.

Tabel 2.1. Kode Warna Resistor

\begin{tabular}{|l|l|}
\hline WARNA & NILAI \\
\hline Hitam & 0 \\
\hline Coklat & 1 \\
\hline Merah & 2 \\
\hline Orange & 3 \\
\hline Kuning & 4 \\
\hline Hijau & 5 \\
\hline Biru & 6 \\
\hline Ungu & 7 \\
\hline Abu - abu & 8 \\
\hline Putih & 9 \\
\hline
\end{tabular}


Tabel 2.2. Nilai Toleransi Resistor

\begin{tabular}{|l|l|}
\hline WARNA & NILAI \\
\hline Emas & $5 \%$ \\
\hline Perak & $10 \%$ \\
\hline Tanpa Warna & $20 \%$ \\
\hline
\end{tabular}

Adapun cara-cara membaca kode warna pada resistor adalah sebagai berikut :

1. Warna yang pertama adalah angka yang pertama.

2. Warna yang ke dua adalah angka yang kedua.

3. Warna yang ke tiga adalah jumlah nol (0) yang mengikuti angka ke dua.

Contoh perhitungan misalnya ada sebuah resistor dengan kode warna hijau, biru, orange, dan emas. Cara mengetahui nilai hambatan pada resistor dengan warna tersebut adalah sebagai berikut :

Warna pertama hijau $=5$, maka kita tuliskan angka pertama adalah 5 . Warna kedua biru $=6$, maka setelah angka pertama, kita tulis angka kedua yaitu angka 6 , sehingga menjadi 56. Selanjutnya warna ketiga orange $=3$ berarti jumlah nol (0) yang mengikuti angka kedua ada $3(000)$, sehingga menjadi $56000=56000 \Omega=56 \mathrm{k} \Omega$. Warna terakhir emas $=5 \%$ berarti nilai toleransi hambatan sebesar $5 \%$.

Dengan demikian kita mengetahui bahwa resistor tersebut mempunyai nilai hambatan sebesar $56 \mathrm{k} \Omega$, dengan toleransi hambatan sebesar $5 \%$. Untuk lebih jelasnya dapat dilihat pada gambar 2.2 berikut ini :

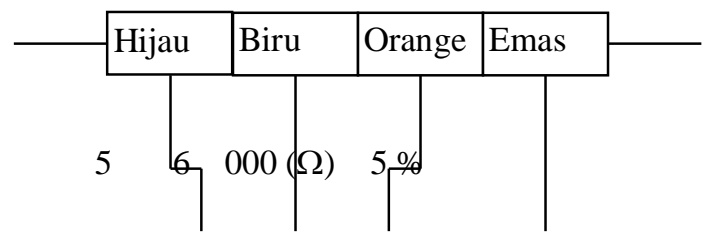

Gambar 2.2. Cara Membaca Kode Warna Resistor

Dalam teori hambatan kita mengenal hukum ohm yang menjelaskan bahwa: $\mathrm{V}=\mathrm{I}$

X R. (1)

Keterangan : $\quad \mathrm{V}=$ Tegangan $($ Volt $)$

$\mathrm{I}=$ Arus (Ampere)

$\mathrm{R}=$ Hambatan $(\mathrm{Ohm})$

Yakni bahwa nilai tegangan berbanding lurus dengan nilai arus dan berbanding terbalik denagn nilai hambatan.

2.2 Induktor (L)

Induktor adalah komponen elektronika yang terbuat dari kawat email yang digulung sedemikian rupa sehingga mempunyai nilai-nilai tertentu dan dapat digunakan untuk nilainilai tertentu. Dalam tugas akhir ini komponen induktor digunakan sebagai :

a. Osilator, yang berfungsi untuk menghasilkan sinyal frekuensi. Induktor digunakan sebagai umpan balik dari sebuah penguat sehingga terjangkit gelombang yang mempunyai frekuensi. Sedangkan frekuensinya dapat diatur dengan memutar inti verit karena induktor ini digulung pada inti verit yang bisa diatur, sehingga gelombang frekuensinya pun bisa diatur sesuai dalam batas-batas tertentu.

b. Relay, adalah saklar elektromagnetik. Relay ini bisa memutus dan menghubungkan suatu rangkaian jika ia diberi arus atau tegangan sesuai dengan kemampuannya. Dalam kajian ini relay digunakan sebagai saklar untuk memutus dan menyambungkan lampu listrik, dan juga untuk memutus dan menyambungkan pulsa ke saklar sinyal. Simbol relay dapat

ELKOM Vol. 12, No. 2, Desember 2019: $34-49$ 
dilihat pada gambar 2.3.
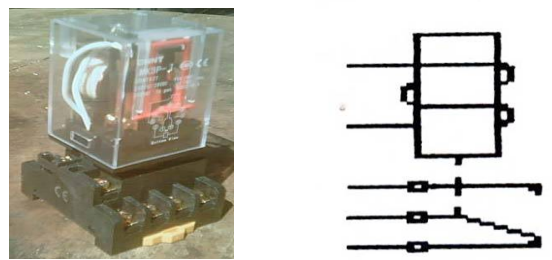

Gb 2.3. Gambar Relay Secara Fisik dan Simbol

c. Kapasitor ( C ) , adalah salah satu komponen pasif dalam elektronika yang berfungsi sebagai :

- pelewat atau pelolos arus bolak-balik (AC).

- penyimpan sementara arus searah (DC).

Nilai kapasitif sebuah kapasitor biasanya sudah tertulis pada kapasitor itu sendiri. Cara membaca nilai kapasitor hampir sama dengan cara membaca resistor. Misalkan pada sebuah kapasitor ditulis harga kapasitor tersebut adalah" 502 ", maka nilai sebenarnya adalah $5000 \mathrm{pF}=5 \mathrm{nF}$. Simbol kapasitor dapat dilihat pada gambar 2.4.

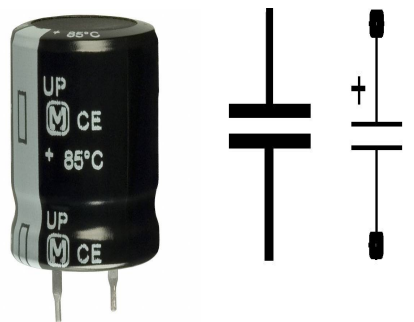

Gb 2.4. Gambar Kapasitor Secara Fisik dan Simbol

Kapasitor mempunyai nilai-nilai tertentu dan dapat melewatkan arus ac dengan frekuensi tertentu pula. Rumus untuk menentukan nilai reaktansi kapasitif (Xc) sebuah kapasitor terhadap frekuensi tertentu adalah :

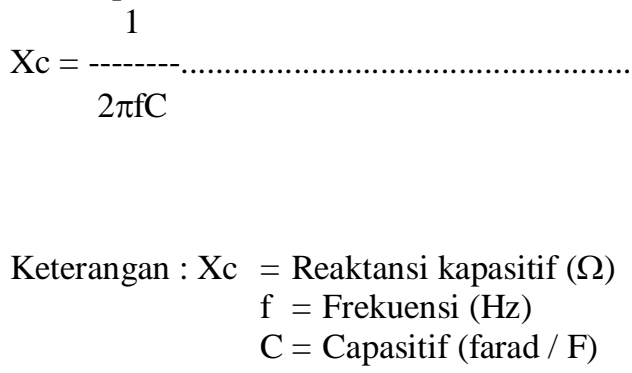

$$
\begin{aligned}
\text { Keterangan : Xc } & =\text { Reaktansi kapasitif }(\Omega) \\
\mathrm{f} & =\text { Frekuensi }(\mathrm{Hz}) \\
\mathrm{C} & =\text { Capasitif }(\text { farad } / \mathrm{F})
\end{aligned}
$$

\subsection{Komponen Aktif}

Komponen aktif adalah kebalikan dari komponen pasif. Jika komponen pasif dapat bekerjatanpa diberikan tegangan atau catu daya terlebih dahulu namun komponen aktif akan dapat bekerja jika ia diberikan tegangan atau catu daya terlebih dahulu.

Seperti halnya komponen pasif, komponen aktif ini juga ada beberapa macam diantaranya ; dioda, transistor, IC. Berikut akan dibahas secara singkat mengenai komponen-komponen tersebut.

1. Dioda

Dioda termasuk dalam komponen aktif. Dioda mempunyai dua buah elektrode yaitu anoda dan katoda. Simbol dioda dapat dilihat pada gambar 2.5. Dioda mempunyai dua buah tegangan bias yaitu bias maju (forward) dan bias mundur (reverse). Cara pemberian tegangan bias maju dan bias mundur dapat dilihat pada gambar 2.6a dan gambar 2.6b. Dioda 
mempunyai banyakfungsi diantaranya sebagai penyearah tegangan dan penahan tegangan. Dalam kajian ini dioda digunakan sebagai penyearah dan juga sebagai pengaman rangkaian.

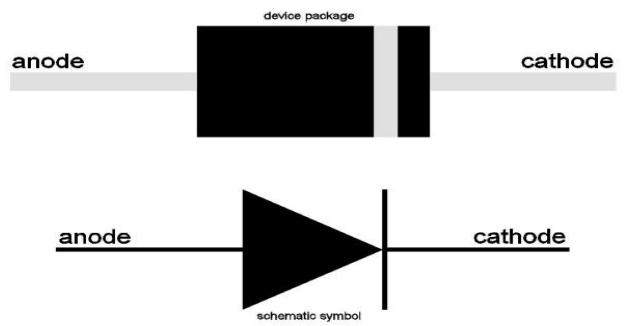

Gb 2.5. Gambar Dioda Secara Fisik dan Simbol

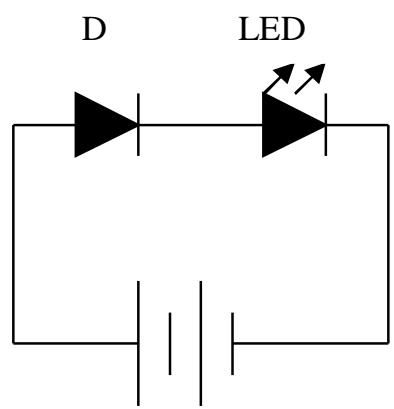

(a). Forward

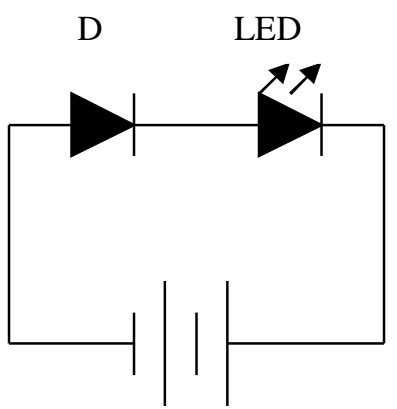

(b). Reverse

Gb 2.6. Bias Maju dan Bias Mundur Dioda

Pada gambar di atas, gambar 2.6a lampu led akan menyala karena dioda menghantarkan arus dari anoda ke katoda. Sedangkan gambar 2.6b lampu led akan padam karena dioda tidak akan menghantarkan arus justru kebalikannya yaitu dioda kan menghambat arus sehingga tidak ada arus yang akan mengalir. Dengan melihat contoh pada gambar 2.6a maka dioda dapat digunakan sebagai penyearah tegangan. Dan dengan melihat contoh gambar $2.6 \mathrm{~b}$ maka dioda dapat difungsikan sebagai pengahambat arus dan dapat mengamankan rangkaian dari arus yang tidak dibutuhkan.

2. Transistor

Transistor mempunyai banyak macam dan jenis, yang masing-masing mempunyai penggunaan dan karakteristik tersendiri. Tipe transistor ada 2 macam yaitu NPN dan PNP. Dalam kajian ini penulis hanya akan membahas tentang transistor NPN, karena yang digunakan dalam pembuatan Tugas Akhir ini semuanya adalah transistor dengan tipe NPN. Simbol transistor dapat dilihat pada gambar 2.7. Transistor mempunyai tiga elektroda yaitu elektroda Basis (B), Kolektor (C), dan emitor (E).

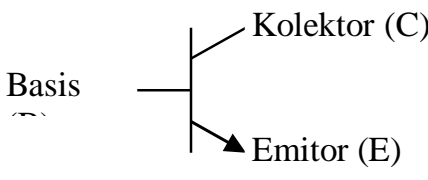

(a). Simbol Transistor NPN

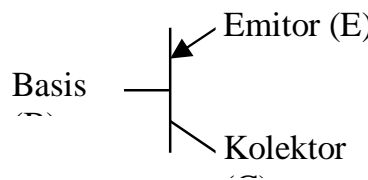

(b). Simbol Transistor PNP

ELKOM Vol. 12, No. 2, Desember 2019: $34-49$ 


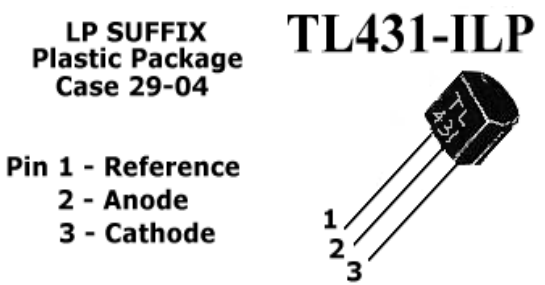

Gb 2.7. Gambar Transistor Secara Simbol dan Fisik

Pada dasarnya transistor NPN mempunyai konstruksi sandwich ( berlapis dua, ada lapisan lain didalamnya) yaitu terdiri dari dua buah hubungan PN dengan sisi disebut kolektor dan emitor, sedangkan ditengah disebut elektroda basis. Cara kerja transistor sebagai berikut : Bila tegangan DC diberikan pada terminal-terminal transistor, dengan hubungan PN, kolektor basis diberi tegangan bias mundur, maka tidak akan ada arus yang mengalir, seperti terlihat pada gambar 2.8. Dan bila pada hubungan PN basis - emitor diberi tegangan bias maju maka akan ada arus yang mengalir (lihat gambar 2.9). Transistor mempunyai 3 macam arus, yaitu arus basis ( IB ), arus kolektor ( IC ), dan arus emitor ( IE ).

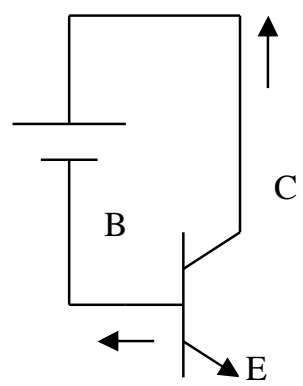

Gb 2.8. Elektroda Basis Kolektor diberi Bias Mundur

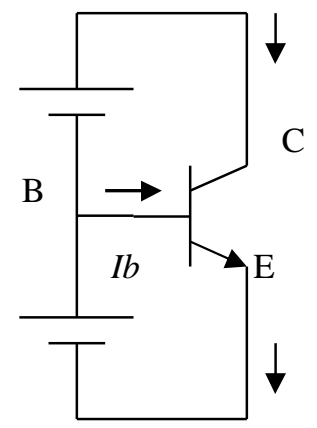

Gb 2.9. Elektroda Basis - Emitor diberi Bias Maju

Besarnya arus emitor (Ie) adalah jumlah dari arus basis (Ib) dan arus kolektor (Ic), Ie = Ib + Ic. Ilustrasi perbandingan arus basis, arus kolektor dan arus emitor dapat dilihat pada gambar 2.10. Dari perbandingan tersebut dapat diketahui bahwa arus basis yang sangat kecil dapat mengontrol arus kolektor yang besar. Maka dapat dikatakan bahwa transistor mempunyai fungsi penguatan arus, dan perbandingan perubahan arus kolektor dengan perubahan arus basis disefinisikan sebagai faktor penguatan arus $(h f e)$; yaitu $h f e=I c / I b$. Pada umumnya $h f e$ transistor berharga sekitar 50 - 500 kali.

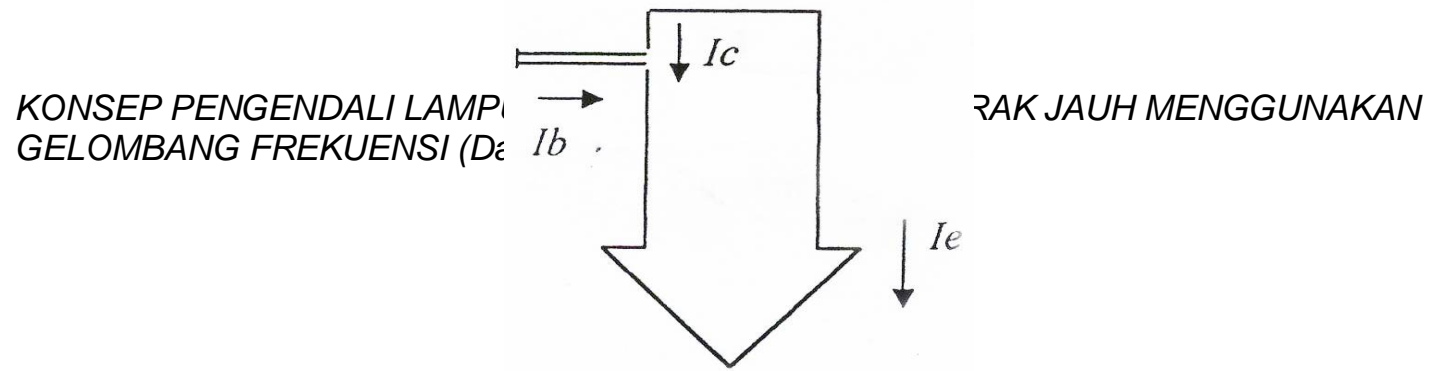


Gb 2.10. Perbandingan Arus Basis, Kolektor, dan Emitor

3. Integrated Circuit (IC)

Integrated Circuit ( IC ) adalah komponen elektronika yang merupakan gabungan dari komponen aktif dan komponen pasif. IC mempunyai bebagai jenis dan fungsinya pun berbeda - beda antara jenis satu dengan jenis yang lain. Fungsi IC biasanya dapat diketahui dari nomor seri yang dibuat oleh pabrik pembuat IC tersebut. Dalam rangkaian kali ini akan dibahas mengenai karakter serta fungsi dari IC transmitter ( TX - 2 ) dan receiver $(\mathrm{RX}-2$, persamaannya $=\mathrm{SM} 6135)$.

a. IC TX - 2

IC TX - 2 adalah IC transmitter yang berfungsi membangkitkan sinyal berbentuk pulsa - pulsa yang nantinya akan dikirimkan ke pesawat penerima dengan menggunakan gelombang berfrekuensi tinggi ( $45 \mathrm{Mhz}$ ).

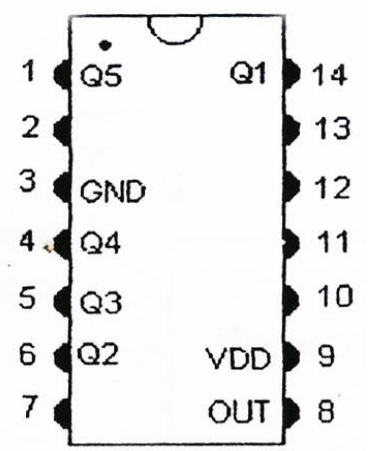

Gb 2.11. IC TX - 2

b. IC RX - 2 / SM6135

IC $\mathrm{RX}-2$ ini adalah IC receiver yang berfungsi menerima sinyal yang telah dikirimkan oleh pesawat pemancar. IC ini memisahkan dan membedakan masing masing pulsa yang telah diterimanya.

\section{Metodologi}

Seperti yang telah diungkapkan di atas bahwa pengendali lampu rumah dari jarak jauh ini bekerja dengan bantuan gelombang frekuensi tinggi / RF yang dipancarkan lewat udara oleh sebuah rangkaian pemancar dan selanjutnya diterima dan diolah oleh sebuah rangkaian penerima. Cara kerja rangkaian dapat dilihat pada gambar 2.12 .

ELKOM Vol. 12, No. 2, Desember 2019: $34-49$ 


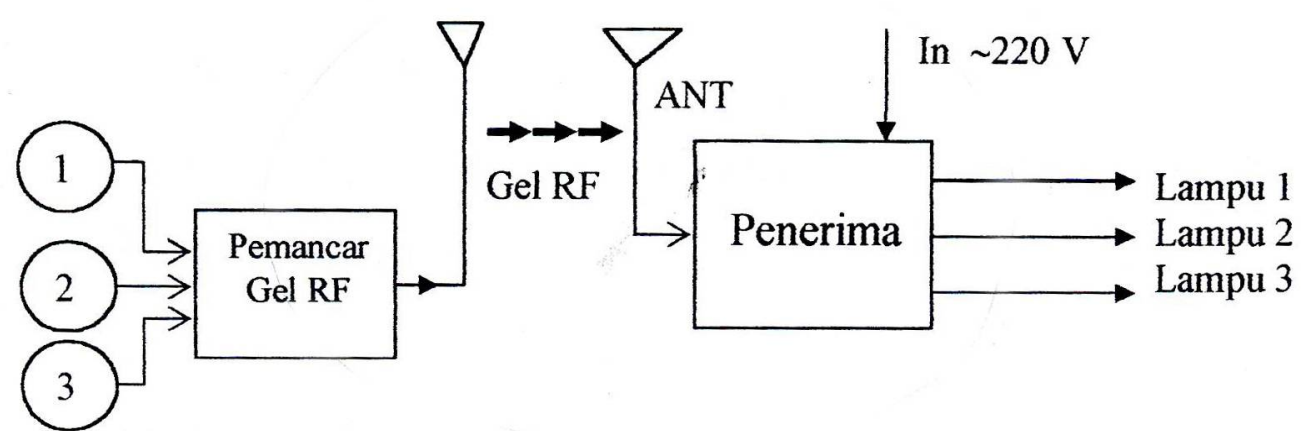

Gb 2.12. Cara Kerja Pengendali Lampu Jarak Jauh

Mula - mula pulsa dibangkitkan oleh pembangkit pulsa yaitu dengan menekan tombol 1, 2, dan 3. Kemudian pulsa - pulsa tersebut dibawa oleh pemancar untuk dikirimkan ke rangkaian penerima lewat udara. Gelombang RF akan diterima oleh rangkaian penerima karena di dalam rangkaian penerima terdapat penala gelombang dengan frekuensi yang sama seperti pada pemancar. Selanjutnya oleh rangkaian penerima, gelombang RF dan sinyal asli yang berupa pulsa tersebut selanjutnya digunakan untuk mengendalikan saklar sinyal yang ada pada pesawat penerima. Pada saklar sinyal ini terdapat saklar kontak relay untuk mengendalikan lampu penerangan. Maka dengan mengendalikan saklar sinyal juga berarti mengendalikan lampu penerangan.

Pengendali rumah jarak jauh adalah aplikasi dari sebuah rangkaian pemancar RF dan penerimanya yang dipadukan dengan sebuah saklar sinyal. Saklar sinyal yaitu sebuah rangkaian saklar yang dapat dihidupkan atau dimatikan oleh sebuah sinyal.

Untuk pembuatan alat terlebih dahulu kita membuat PCB dari masing - masing rangkaian, kemudian memasangkan komponen - komponen yang telah disiapkan pada PCB sesuai dengan tempatnya. Dengan demikian maka rangkaian akan dapat bekerja dengan baik. PCB pemancar tampak dari atas dan tampak dari bawah dapat dilihat pada gambar 3.12 dan 3.13. Sedangkan PCB penerima tampak dari atas dan tampak dari bawah dapat dilihat pada gambar 3.14 dan 3.15.

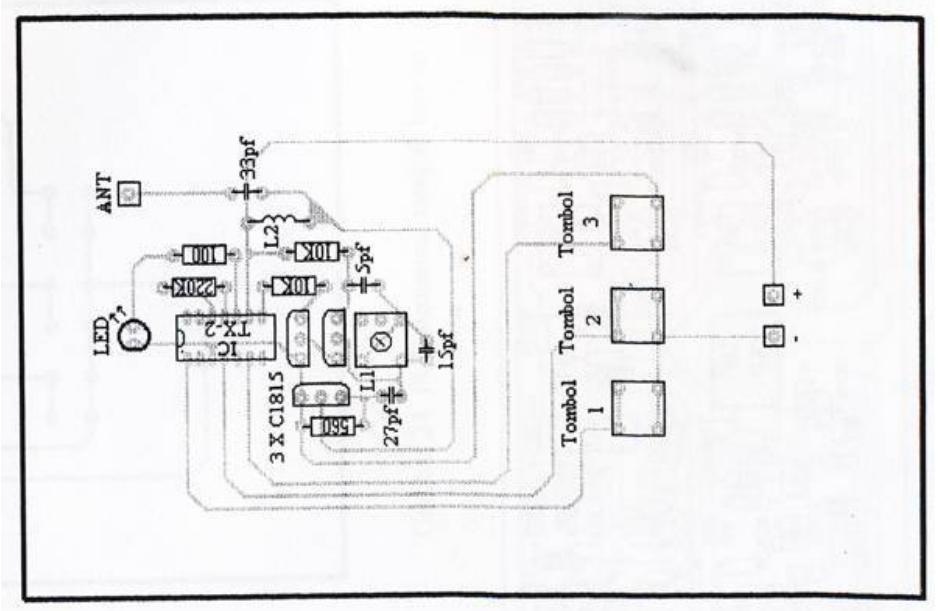

Gb 3.12. PCB Pemancar Tampak Atas

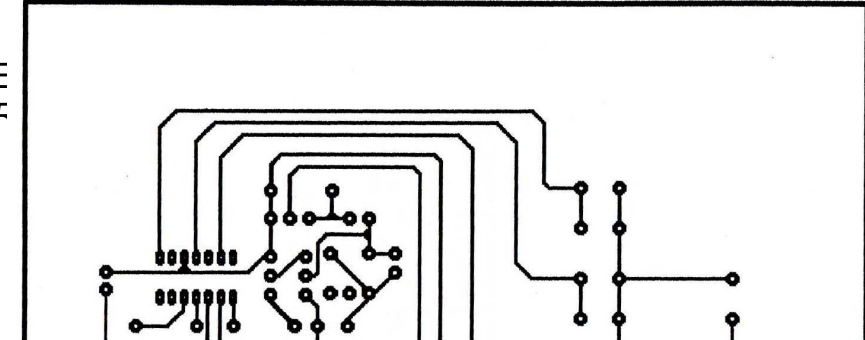


Gb 3.13. PCB Pemancar Tampak Bawah

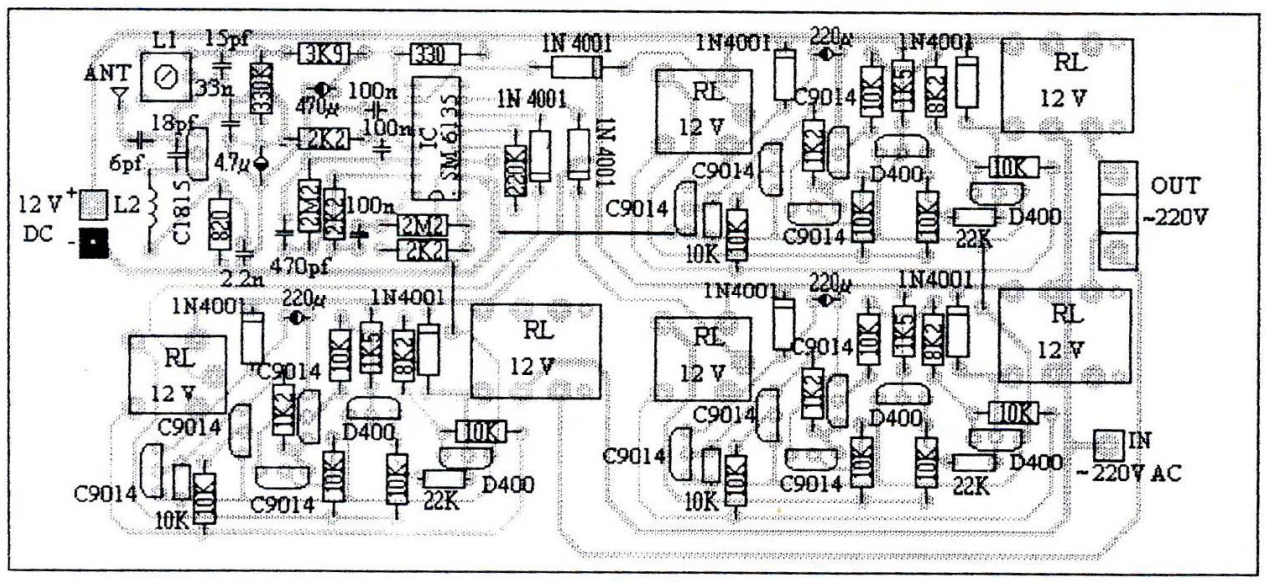

Gb 3.14. PCB Penerima Tampak Atas

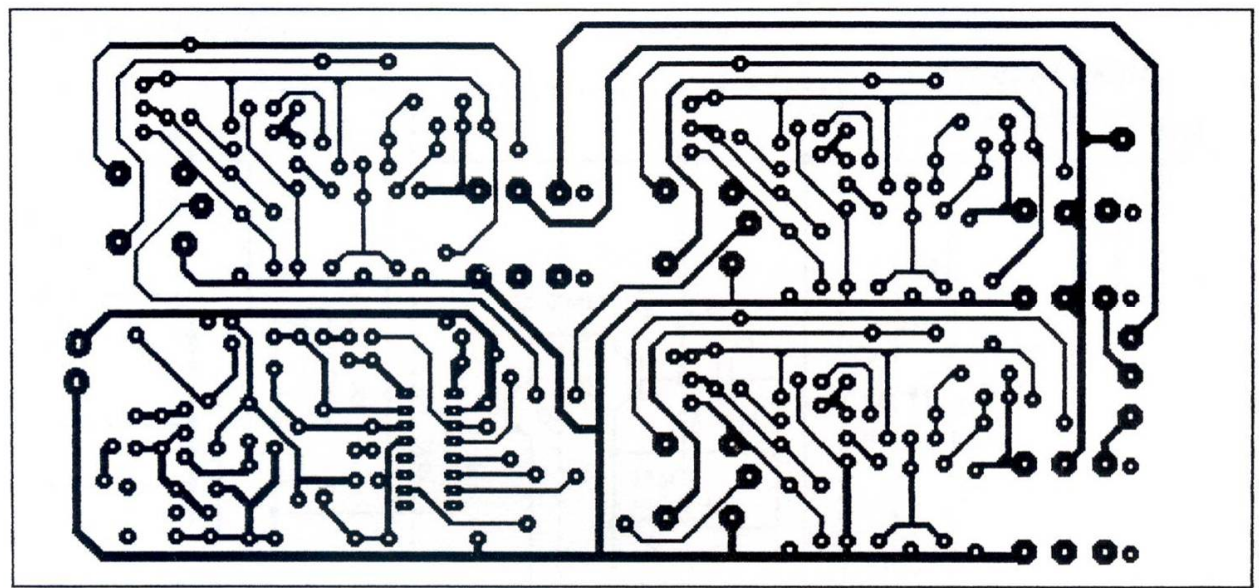

Gb 3.15. PCB Penerima Tampak Bawah

ELKOM Vol. 12, No. 2, Desember 2019 : $34-49$ 


\section{Hasil dan Pembahasan}

Dari rangkaian pemancar dan penerima yang telah dibuat, dilakukan pengujian dengan mengukur tegangan dan bentuk sinyal yang dikeluarkan oleh rangkaian. Dengan menggunakan osiloscop kita bisa mengetahui tegangan dan bentuk sinyal yang dikeluarkan oleh masing - masing rangkaian tersebut.

\section{a. Pengujian Rangkaian Pemancar}

Dalam pengujian rangkaian pemancar ini kita akan mengukur besar tegangan dan bentuk sinyal output pemancar. Rangkaian pemancar dalam pengujian dapat dibagi menjadi tiga bagian atau blok yaitu : pembangkit pulsa, osilator RF, dan penguat akhir, yang mana pada output masing - masing blok tersebut mempunyai bentuk sinyal yang berbeda - beda. Bagian dari blok - blok tersebut dapat dilihat pada gambar 4.1.

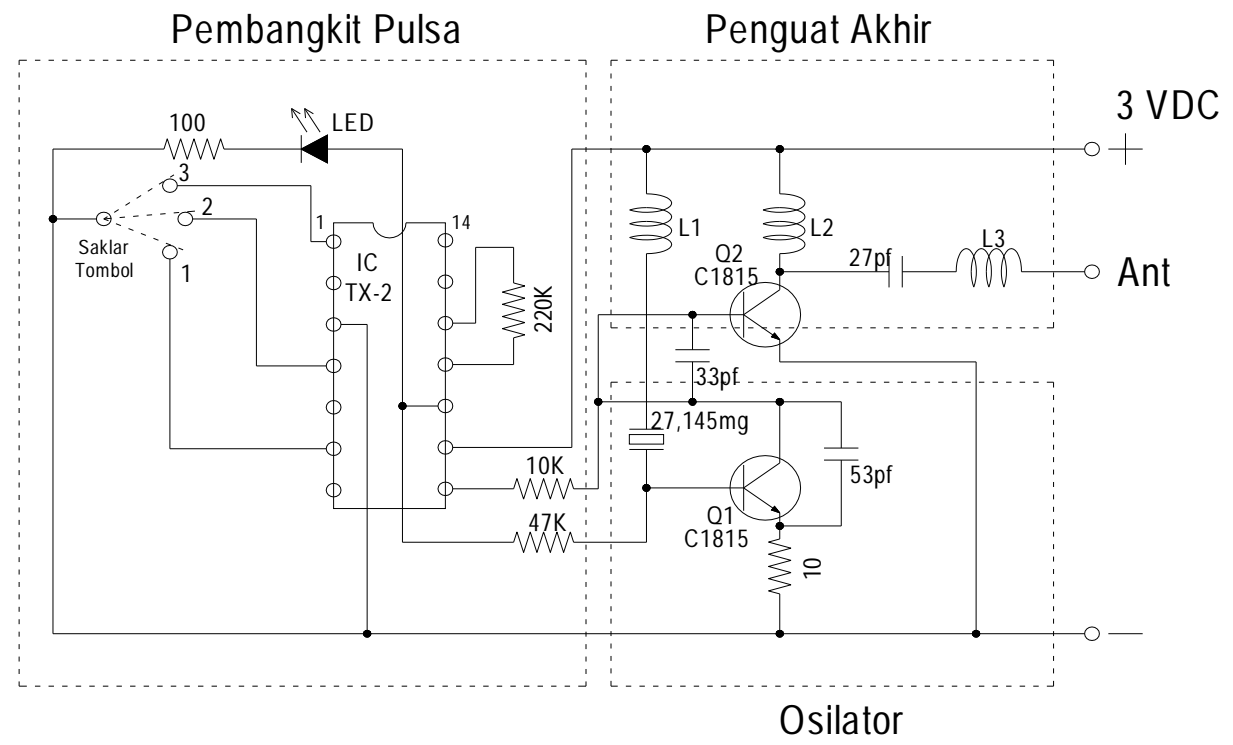

Gb 4.1. Pembagian Blok Pada Pemancar

1. Pembangkit Pulsa

Sinyal berupa pulsa dibangkitkan oleh IC TX-2. Input tegangan IC pada rangkaian pemancar ini adalah $3 \mathrm{Vdc}$. Hasil keluaran dari IC tersebut adalah pada kaki IC nomor 8, dari hasil pengukuran pembangkit pulsa didapatkan data sebagai berikut :

Tombol 1 : $1,5 \mathrm{Vdc}$

Tombol $2: 1,48 \mathrm{Vdc}$

Tombol $3: 1,49 \mathrm{Vdc}$

Tegangan input kaki 1, 4 dan 6 pada saat saklar tombol tidak dipencet adalah $0,7 \mathrm{Vdc}$ sedangkan pada saat saklar dipencet adalah $0 \mathrm{Vdc}$ karena digroundkan.

Bentuk sinyal :

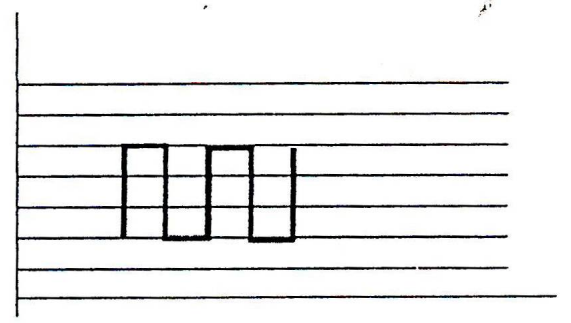

2. Osilator RF

Gb 4.2. Hasil Keluaran Pembangkit Pulsa 
Osilator RF ini membangkitkan gelombang RF dengan frekuensi $27 \mathrm{MHz}$. Gelombang RF diperlukan untuk mengirim pulsa dari pemancar menuju ke penerima. Dari hasil pengujian osilator RF didapatkan data sbb :

Berikut ini hasil pengukuran untuk masing - masing transistor Q1 dan Q2 :

1. Pada saat saklar tidak dipencet :

$$
\text { Q1: } \begin{aligned}
\mathrm{B} & =0 \\
\mathrm{C} & =3 \mathrm{~V} \\
\mathrm{E} & =0
\end{aligned}
$$

2. Pada saat saklar dipencet :

$$
\begin{aligned}
\mathrm{Q} 1: \mathrm{B} & =0,4 \mathrm{~V} \\
\mathrm{C} & =3 \mathrm{~V} \\
\mathrm{E} & =0
\end{aligned}
$$

Bentuk sinyal :

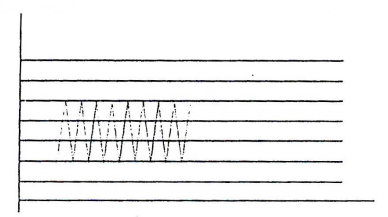

Gb 4.3. Hasil Keluaran dari Osilator RF

3. Penguat Akhir

Penguat akhir merupakan rangkaian paling akhir dari pemancar. Pada output akhir ini, pulsa yang dibangkitkan telah dimodulasikan pada gelombang RF dan telah dikuatkan. Hasil pengujian penguat akhir adalah sebagai berikut :

Berikut ini hasil pengukuran untuk masing - masing transistor Q1 dan Q2 :

1. Pada saat saklar tidak dipencet :

$$
\begin{aligned}
\text { Q2 : } & \text { B }=0 \\
\mathrm{C} & =3 \mathrm{~V} \\
\mathrm{E} & =0
\end{aligned}
$$

2. Pada saat saklar dipencet :

$$
\begin{aligned}
\text { Q2: } \mathrm{B} & =0,09 \mathrm{~V} \\
\mathrm{C} & =3 \mathrm{~V} \\
\mathrm{E} & =0
\end{aligned}
$$

Bentuk sinyal :

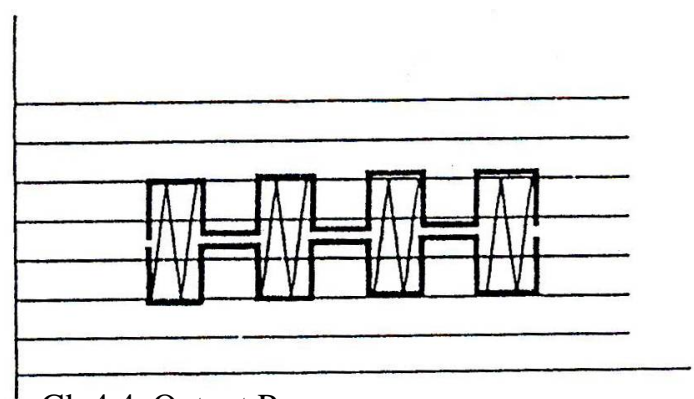

Gb 4.4. Output Pemancar

\section{b. Pengujian Rangkaian Penerima}

Seperti yang telah dilakukan pada rangkaian pemancar, pengujian rangkaian penerima juga akan mengukur tegangan dan bentuk sinyalnya kecuali untuk saklar sinyal. Blok rangkaian dapat dilihat pada gambar 4.5 dan 4.6.

ELKOM Vol. 12, No. 2, Desember 2019: $34-49$ 


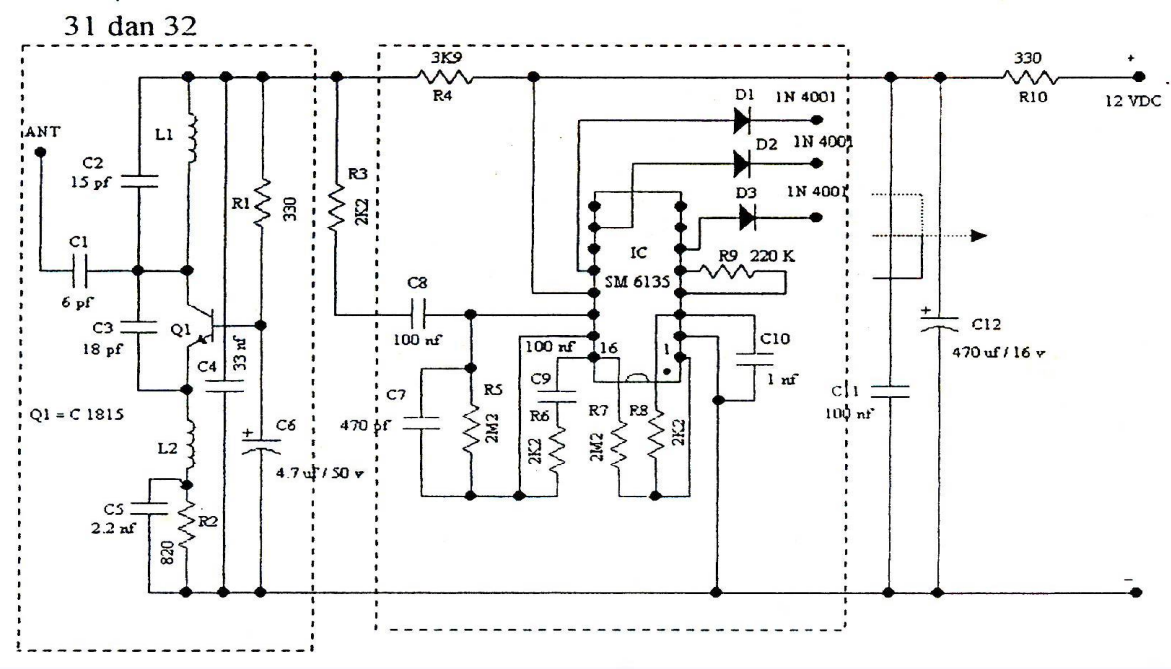

Gb 4.5. Blok Rangkaian Penerima

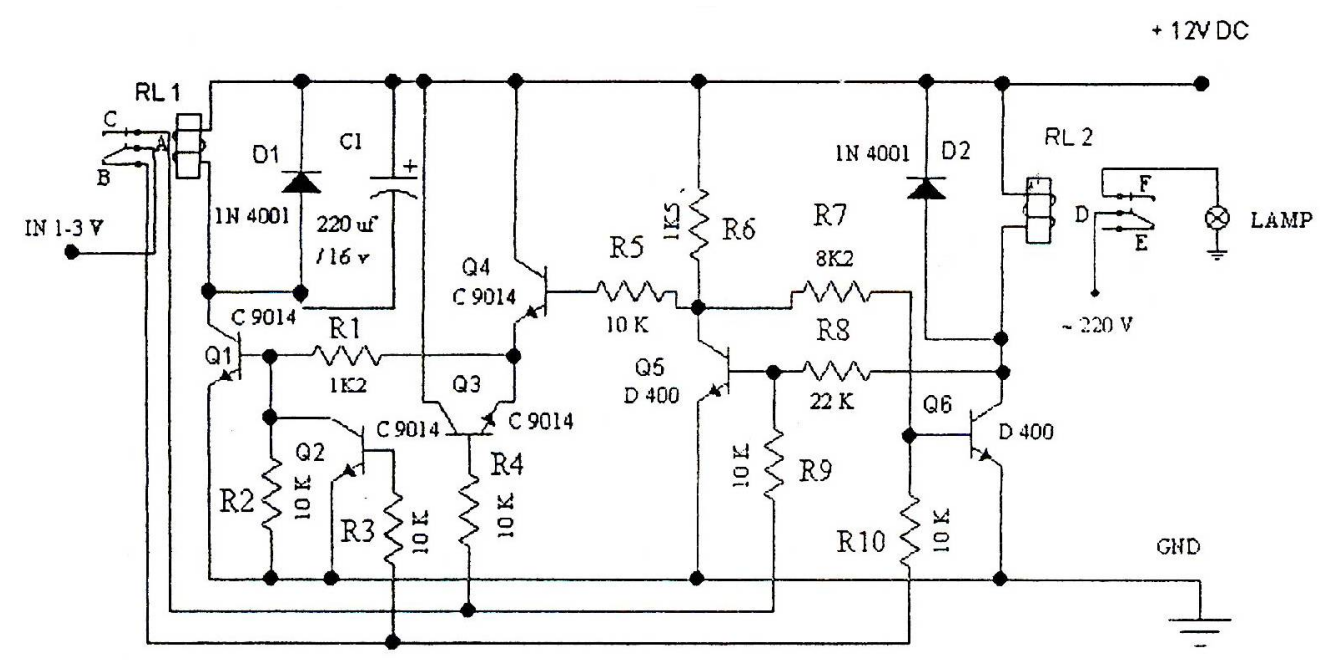

Gb 4.6. Rangkaian Saklar Sinyal

1. Penerima Gelombang RF

Sinyal berupa gelombang RF yang dipancarkan oleh pemancar selanjutnya akan ditangkap oleh rangkaian penerima dengan menggunakan penerima gelombang RF ini. Bentuk gelombang yang ditangkap sama persis seperti gelombang yang dipancarkan oleh pemancar yaitu yang dikeluarkan oleh penguat akhir. 


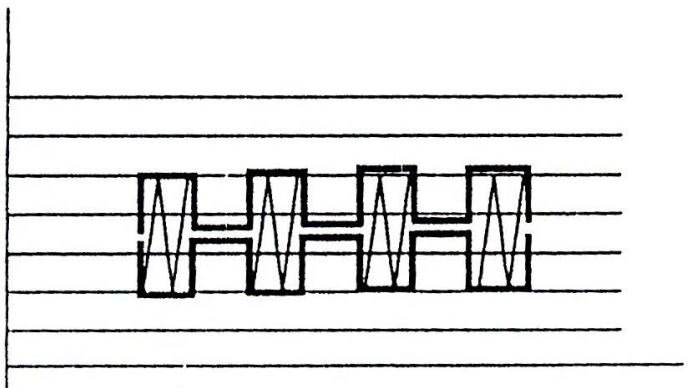

Gb 4.7. Gelombang yang diterima oleh rangkaian penerima

2. Pemisah sinyal

Gelombang RF yang diterima kemudian dipisahkan oleh pemisah sinyal dan selanjutnya pulsa - pulsa yang ada didalamnya akan dipisahkan oleh IC SM 6135 sesuai dengan jumlah pulsa. Bentuk gelombang setelah dipisahkan akan menjadi seperti bentuk gelombang yang dibangkitkan pembangkit pulsa pada rangkaian pemancar.

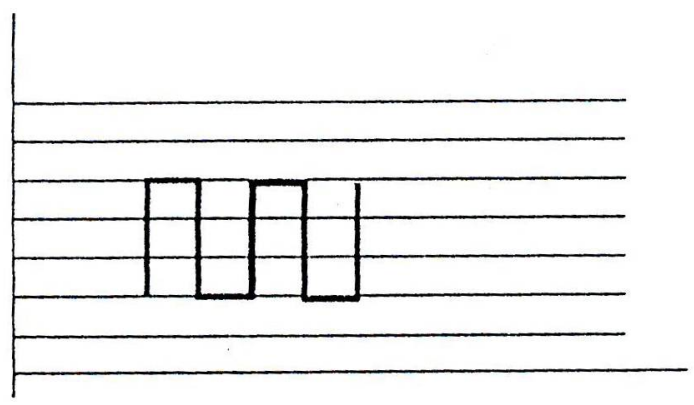

Gb 4.8. Pulsa yang telah dipisahkan dari gelombang RF

Tegangan input IC pada rangkaian penerima ini adalah 9 Vdc. Berikut ini hasil pengukuran untuk tiap kaki IC penerima (SM 6135) :

1. Pada saat tombol tidak ditekan :

$\begin{array}{llll}\text { kaki } 1=2 \mathrm{Vdc} & \text { kaki } 1 & =0 \mathrm{Vdc} \\ \text { kaki } & 2=0 \mathrm{Vdc} & \text { kaki } 10=0 \mathrm{Vdc} \\ \text { kaki } & 3=2 \mathrm{Vdc} & \text { kaki } 11=0 \mathrm{Vdc} \\ \text { kaki } & 4=0 \mathrm{Vdc} & \text { kaki } 12=0 \mathrm{Vdc} \\ \text { kaki } & 5=2 \mathrm{Vdc} & \text { kaki } 13=4 \mathrm{Vdc} \\ \text { kaki } 6=0 \mathrm{Vdc} & \text { kaki } 14=0 \mathrm{Vdc} \\ \text { kaki } 7=0 \mathrm{Vdc} & \text { kaki } 15=2 \mathrm{Vdc} \\ \text { kaki } & 8=0 \mathrm{Vdc} & \text { kaki } 16=0 \mathrm{Vdc}\end{array}$

2. Pada saat tombol 1 ditekan :
kaki $1=2 \mathrm{Vdc}$
kaki $1=0 \mathrm{Vdc}$
kaki $2=0 \mathrm{Vdc}$
kaki $10=0 \mathrm{Vdc}$
kaki $3=2 \mathrm{Vdc}$
kaki $11=0 \mathrm{Vdc}$
kaki $4=0 \mathrm{Vdc}$
kaki $12=4,5 \mathrm{Vdc}$
kaki $5=2 \mathrm{Vdc}$
kaki $13=4 \mathrm{Vdc}$
kaki $6=0 \mathrm{Vdc}$
kaki $14=0 \mathrm{Vdc}$
kaki $7=0 \mathrm{Vdc}$
kaki $15=2 \mathrm{Vdc}$
kaki $8=0 \mathrm{Vdc}$
kaki $16=0 \mathrm{Vdc}$

Pada saat tombol 1, 2 atau 3 ditekan semua pengukuran pada kaki IC sama, namun yang berbeda yaitu saat tombol 2 ditekan IC kaki $10=4,5$ Vdc sedangkan jika 
tombol 3 ditekan maka output yang berubah adalah pada kaki IC nomor 6 yaitu sebesar 4 , $5 \mathrm{Vdc}$.

3. Saklar Sinyal

Cara pengujian saklar sinyal ini tidak melihat bentuk gelombang yang dihasilkan, namun dengan cara memasukkan tegangan berbentuk pulsa ataupun sinus sebesar 3-5 V ke dalam input rangkaian. Lebih jelasnya sebagai berikut :

Pertama masukkan tegangan kedalam input saklar sinyal sebesar $3-5$ V. Jika rangkaian berfungsi dengan baik maka lampu yang dipasangkan pada saklar sinyal akan menyala, dan meskipun tegangan yang dimasukkan sudah diputus / dilepas lampu akan tetap menyala.

Setelah lampu menyala kemudian masukkan kembali tegangan sebesar 3 - $5 \mathrm{~V}$ kedalam input rangkaian untuk kedua kalinya, maka lampu akan padam, dan meskipun input sudah diputus lampu akan tetap padam.

Pada rangkaian saklar sinyal terdapat 6 buah transistor. Berikut hasil pengukuran dari transistor Q1 - Q6:

1. Sakelar pada rangkaian pemancar tidak ditekan :
Q1 : $\mathrm{B}=0,7 \mathrm{Vdc}$
$\mathrm{C}=0 \mathrm{Vdc}$
$\mathrm{E}=0 \mathrm{Vdc}$
Q4 : $\mathrm{B}=7 \mathrm{Vdc}$
$\mathrm{C}=9 \mathrm{Vdc}$
$\mathrm{E}=6 \mathrm{Vdc}$
Q2 : $\mathrm{B}=0,7 \mathrm{Vdc}$
$\mathrm{C}=0,7 \mathrm{Vdc}$
$\mathrm{E}=0 \mathrm{Vdc}$
Q5 : $\mathrm{B}=0 \mathrm{Vdc}$
$\mathrm{C}=7,8 \mathrm{Vdc}$
$\mathrm{E}=0 \mathrm{Vdc}$
Q3 : $\mathrm{B}=0 \mathrm{Vdc}$
$\mathrm{C}=9 \mathrm{Vdc}$
$\mathrm{E}=7 \mathrm{Vdc}$
Q6 : $\mathrm{B}=0,6 \mathrm{Vdc}$
$\mathrm{C}=0 \mathrm{Vdc}$
$\mathrm{E}=0 \mathrm{Vdc}$

1. Sakelar pada rangkaian pemancar tidak ditekan :
Q1 : $\mathrm{B}=0 \mathrm{Vdc}$
$\mathrm{C}=0 \mathrm{Vdc}$
$\mathrm{E}=9 \mathrm{Vdc}$
Q4 : $\mathrm{B}=0 \mathrm{Vdc}$
$\mathrm{C}=9 \mathrm{Vdc}$
$\mathrm{E}=3 \mathrm{Vdc}$
Q2 : $\mathrm{B}=0 \mathrm{Vdc}$
$\mathrm{C}=0 \mathrm{Vdc}$
$\mathrm{E}=0 \mathrm{Vdc}$
Q3 : $\mathrm{B}=3 \mathrm{Vdc}$
$\mathrm{C}=9 \mathrm{Vdc}$
$\mathrm{E}=3 \mathrm{Vdc}$
$\mathrm{C}=0 \mathrm{Vdc}$
$\mathrm{E}=0 \mathrm{Vdc}$
Q5 : $\mathrm{B}=0,6 \mathrm{Vdc}$
Q6 : $\mathrm{B}=0 \mathrm{Vdc}$
$\mathrm{C}=9 \mathrm{Vdc}$
$\mathrm{E}=0 \mathrm{Vdc}$

\section{B. Pengujian Fungsi Alat}

Setelah dilakukan pengukuran dengan menggunakan alat ukur osiloscope, langkah selanjutnya adalah melakukan pengujian terhadap fungsi dan kemampuan alat secara keseluruha. Pada bagian pemancar atau remote control terdapat tiga buah tombol yang masing - masing berfungsi untuk mengendalikan sebuah lampu penerangan. Tombol 1 berfungsi untuk mengendalikan lampu pertama, tombol 2 berfungsi untuk mengendalikan lampu ke dua, dan tombol 3 berfungsi mengendalikan lampu ke tiga.

Kemampuan jarak yang dapat dijangkau alat ini kurang lebih adalah 35 meter. Hal ini dapat dilihat dari hasil pengujian jarak jangkauan dapat dilihat pada tabel 4.1. Dengan melihat tabel 4.1, maka dapat diketahui bahwa jarak maksimal yang dapat dijangkau oleh pemancar / remote control untuk mengendalikan lampu yang ada pada rangkaian penerima adalah 35 meter. 
Tabel 4.1. Hasil Pengujian Jarak Jangkauan Pemancar dan Penerima

\begin{tabular}{|l|l|l|l|l|}
\hline \multirow{2}{*}{$\begin{array}{l}\text { Bagian Tombol } \\
\text { yang ditekan }\end{array}$} & $\begin{array}{l}\text { Jarak Jangkauan Pemancar } \\
\text { \& Penerima } \\
(\mathrm{m})\end{array}$ & Kondisi Lampu & \multicolumn{3}{l|}{} \\
\cline { 2 - 5 } & 5 & Lampu 1 & Lampu 2 & Lampu 3 \\
\hline Tombol 1 & 10 & Menyala & Padam & Padam Padam \\
& 15 & Menyala & Padam & Padam Padam \\
& 20 & Menyala & Padam & Padam Padam \\
& 25 & Menyala & Padam Padam & \\
& 30 & Menyala & Padam & \\
& 35 & Menyala & Padam & \\
& 40 & Padam & Padam & \\
\hline Tombol 2 & 5 & & Menyala & \\
& 10 & Padam Padam & Menyala & \\
& 15 & Padam Padam & Menyala & Padam Padam \\
& 20 & Padam Padam Padam & Menyala & Padam Padam \\
& 25 & Padam Padam & Menyala & Padam Padam \\
& 30 & & Menyala & \\
& 35 & & Padam & \\
\hline Tombol 3 & 50 & & Padam & Menyala \\
& 5 & & Padam & Menyala 35 \\
& 10 & Padam Padam & Padam & Menyala \\
& 15 & Padam Padam & Padam & Menyala \\
& 20 & Padam Padam & Padam & Menyala \\
& 25 & Padam Padam & Padam & Menyala \\
& 30 & & Padam & Menyala \\
& 35 & Padam & Padam \\
\hline
\end{tabular}

Catatan : Pengujian dilakukan pada kondisi antena pemancar dan antena penerima ditarik pada posisi maksimal.

\section{Kesimpulan}

Dari pembahasan dan pengujian yang telah dilakukan dapat diambil kesimpulan antara lain senagai berikut :

1. Gelombang berfrekuensi tinggi (RF) dapat membawa sinyal berupa pulsa yang dibangkitkan oleh IC pembangkit pulsa. Berdasarkan hasil pengamatan didapat frekuensi pembawa sinyal adalah sama yaitu sebesar $1 \mathrm{kHz}$ sedangkan yang membedakan dari tiap tombol saklar pembangkit pulsa adalah tegangan outputnya yaitu sebesar 1,5 Vdc (sakelar 1), 1,7 Vdc (sakelar 2) dan 1,9 Vdc (sakelar 3).

2. Saklar sinyal pada rangkaian penerima dapat dikendalikan hanya dengan pemberian satu sinyal / pulsa.

3. Kemampuan maksimal rangkaian penerima untuk menangkap gelombang RF dari pemancar adalah $35 \mathrm{~m}$.

\section{Daftar Pustaka}

Http://digilib.unnes.ac.id/gsdl/collect/skripsi/archives/HASH8e91.dir/doc.pdf

Http://www.datasheetcatalog.org/datasheet/philips/1815.pdf

Http://www.futurlec.com/Transistors/C9014.shtml

Http://www.hlec.com.cn/www/pdf/TX-2RX-2.pdf

Http://www.ic-on-line.cn/IOL/datasheet/sm6135_202910.pdf

ELKOM Vol. 12, No. 2, Desember 2019: $34-49$ 
49

Sofyan, 2004, Mencari dan Memperbaiki Kerusakan pada TV berwarna, Jakarta : Pradnya Paramita

Petruzella D. Frank, 2002, elektronika Industri, Yogyakarta : ANDI

Jacob Millman, 1997, Elektronika Terpadu " Rangkaian dan System Analog dan Digital", Jakarta : ERLANGGA.

Reka Rio dan Yoshikatsu Sawamura, 1997, Teknik Reparasi Televisi Berwarna, Jakarta : Pradnya Paramita 